Geosistemy perehodnykh zon = Geosystems of Transition Zones / Геосистемы переходных зон

Content is available under the Creative Commons Attribution 4.0 International License (CC BY 4.0)

2021, vol. 5, No. 3, pp. 275-286

URL: http://journal.imgg.ru/archive.html ; https://elibrary.ru/title about.asp?id=64191

https://doi.org/10.30730/gtrz.2021.5.3.275-286

\title{
Geological evolution of the northern Mid Kuril trough based on seismic facies analysis
}

Vladimir Valentinovich Zhigulev, https://orcid.org/0000-0002-4015-5424, zhvv@dmng.ru

Alexander Vladimirovich Zhigulev

Rosgeo, Dalmorneftegeophysica JSC, Yuzhno-Sakhalinsk, Russia

\section{Abstract $\underline{\text { PDF ENG }}$ Резюме $\underline{\text { PDF RUS }} \quad$ Full text $\underline{\text { PDF RUS }}$}

Abstract. The model of geological evolution of an interarc basin, which is the north-east ending of Mid Kuril trough located on the continental slope of Kuril-Kamchatka trench, was constructed. Seismic facies analysis was first applied to define sedimentation conditions in a deep water trench. The analysis was based on the 2D CDP reflection seismic data obtained by Dalmorneftegeophysica JSC in 2014. According to the modeling results, the basin began to form in the Late Cretaceous and passed several stages. Initial subsidence of a local crust area of the incipient basin changed over to its further separation from the adjacent waters of the Sea of Okhotsk and Pacific Ocean by various volcanic formations framing its contour. The basin waters and the Pacific Ocean waters merged as a result of subsidence and submersion of volcanic structures on the east basin framing at the final stage during the Oligocene-Middle Miocene. This subsidence is directly related to the global processes associated with Kuril-Kamchatka ocean trench appearance such as inherent crust subsidence along valley bottom line accompanied by increase in inclination angle of its flanks. It was concluded that the trench origination time approximately corresponds to the Oligocene-Middle Miocene boundary.

Keywords:

\section{Kuril-Kamchatka ocean trench, Mid Kuril trough, geological evolution, seismic survey, seismic facies analysis}

For citation: Zhigulev V.V., Zhigulev A.V. Geological evolution of the northern Mid Kuril trough based on seismic facies analysis. Geosistemy perehodnykh zon = Geosystems of Transition Zones, 2021, vol. 5, no. 3, pp. 275-286. (In Russ., abstr. in Engl.). https://doi.org/10.30730/gtrz.2021.5.3.275-286

Для цитирования: Жигулев В.В., Жигулев А.В. Геологическое развитие северной части Срединно-Курильского прогиба по данным сейсмофрациального анализа. Геосистемы переходных зон, 2021, т. 5, № 3, с. 275-286. https://doi.org/10.30730/gtrz.2021.5.3.275-286

\section{References}

1. Balakina L.M. 1995. [Kuril-Kamchatka seismogenic zone - the structure and generation order of earthquakes]. Fizika Zemli $=$ Izvestiya, Physics of the Solid Earth, 12: 48-57. (In Russ.).

2. Vasiliev B.I., Zhiltsov E.G., Suvorov A.A. 1979. [Geological structure of the southwestern part of the Kuril arc-trench system]. Moscow: Nauka, 106 p. (In Russ.).

3. [Geological and geophysical atlas of the Kuril island system]. 1987. Leningrad: VSEGEI, 36 p. (In Russ.).

4. Gnibidenko G.S. 1987. [Structure of deep-sea trenches of the Pacific Ocean (based on the data of CDP seismic reflection method)]. Vladivostok: DVO AN SSSR, 50 p. (In Russ.).

5. Lelikov E.P., Tsoi I.B., Emelyanova T.A., Terekhov E.P., Vaschenkova N.G., Vagina N.K., Smirnova O.L., Khudik V.D. 2008. Geological structure of the submarine Vityaz Ridge within the Seismic Gap area (Pacific slope of the Kurile island arc). Russian J. of Pacific Geology, 2(2): 99-109.

6. Lomtev V.L. 1989. Methods of ocean trenches dating Geology of the Pacific Ocean and transitional zone to Asian continent. Vladivostok: DVO AN SSSR, 105-111. (In Russ.).

7. Lomtev V.L. 2012. On structure and history of Kuril-Kamchatka ocean trench (NW Pacific). [Geology and mineral resources of the World Ocean], 3: 36-47. (In Russ.).

8. Lomtev V.L., Patrikeev V.N. 1985. [Compression structures in the Kuril and Japan trenches]. Vladivostok: DVNC AN SSSR, 141 p. (In Russ.).

9. Lomtev V.L., Patrikeev V.N. 2006. Seismic researches of the Institute of Marine Geology and Geophysics FEB RAS in the Northwestern Pacific (1980-2005). Vestnik DVO RAN = Vestnik of the Far East Branch of the RAS, 1: 59-66. (In Russ.).

10. Rybak-Franko Yu.V., Gretskaya E.V., Agadzhanyants I.G. 2019. Geophysical Survey in the water area of the Northern Kuril Islands is a New Page in Understanding of Geological Structure, Evolution and Prospects of the Region's Oil and Gas Potential. In: New Ideas in the Geology of Oil and Gas: Collection of Articles. Scientific Papers (based on the materials of the International Scientific-Practical Conference, May 23-24, 2019): [Electronic resource] (ed. A.V. Stupakov; Lomonosov Moscow State University, Geol. Faculty, Department of Geology and Geochemistry of Fossil Fuels). M.: Pero, p. 408-412.

11. Sergeev K.F. 1976. Tectonics of the Kuril island system. Moscow: Nauka, 240 p. (In Russ.). 
12. Tarakanov R.Z. 2004. [New approach to the nature of seismic focal zone]. In: [Geodynamics, geology and oil and gas bearing capacity of the sedimentary basins of the Russian Far East]. Yuzhno-Sakhalinsk: IMGiG DVO RAN, vol. 1: 157175. (In Russ.).

13. [Tectonics and hydrocarbon potential of the Sea of Okhotsk]. 2004. Vladivostok: DVO RAN, 160 p. (In Russ.).

14. (Sychev P.M., ed.) [Tectonics of Kuril-Kamchatka deep-sea trench]. 1980. Moscow: Nauka, 178 p. (In Russ.).

15. Terekhov E.P., Mozherovsky A.V., Tsoy I.B., Lelikov E.P., Vashchenkova N.G., Gorovaya M.T. 2012. Late Mesozoic and Cenozoic volcanosedimentary complexes from the submarine Vityaz Ridge, the Island Arc slope of the Kuril-Kamchatka trench, and its evolution. Russian J. of Pacific Geology, 6(3): 209-216.

16. Tikhonov I.N., Vasilenko N.F., Zolotukhin D.E., Prytkov A.S., Ivelskaya T.N., Poplavsky A.A., Spirin A.I. 2008. Simushir earthquakes and tsunami of November 15, 2006, and January 13, 2007. Russian J. of Pacific Geology, 2(1): 1-14.

17. Tsoi I.B., Shastina V.V. 2005. Cenozoic siliceous microplankton from the deposits of the Sea of Okhotsk and the KurilKamchatka trench. Vladivostok: Dalnauka, $181 \mathrm{p}$.

18. Sheriff R.E., Geldart L.P. 1987. Exploration seismology. Vol. 2. Moscow: Mir, 400 p. (In Russ., transl. for Engl.). https://doi.org/10.1017/cbo9781139168359

19. Paturet D. 1971. Different methods of time-depth conversion with and without migration. Geophysical Prospecting, 19(1): 27-41. https://doi.org/10.1111/j.1365-2478.1971.tb00584.x

20. Roksandic M.M. 1978. Seismic facies analysis concepts. Geophysical Prospecting, 26: 383-398. https://doi.org/10.1111/j.1365-2478.1978.tb01600.x

21. Sangree J.B., Widmier J.M. 1979. Interpretation of depositional facies from seismic data. Geophysics, 44: 131-60. https://doi.org/10.1190/1.1440957

22. Vail P.R., Todd R.G., Sangree J.B. 1977. Chronostratigraphic significance of seismic reflections. In: Payton C.E. (ed.) Seismic stratigraphy - Applications to Hydrocarbon exploration, Tulsa, AAPG Memoir, 26, pt. 5, p. 99-116. https://doi.org/10.1306/M26490C7 